\title{
PENDAMPINGAN PENGEMASAN DAN PEMASARAN PRODUK-PRODUK UNGGULAN DUSUN CANDIN DESA PULAU MANDANGIN SAMPANG
}

\author{
Oleh: \\ Muslihul Umam ${ }^{1}$, Isabela ${ }^{2}$, Zainuddin ${ }^{3}$, Mabruroh ${ }^{4}$, Moh. Farid ${ }^{5}$ \\ Dosen IAI Nazhatut Thullab Sampang1,2,3, \\ Mahasiswa IAI Nazhatut Thullab Sampang 4,5 \\ E-mail: muslehumam@gmail.com ${ }^{1}$, izzabillahaja@gmail.com ${ }^{2}$, zainuddinsampang1@gmail.com ${ }^{3}$
}

\begin{abstract}
Abstrak:
Tujuan dari Pengabdian ini adalah untuk membantu menyelesaikan permasalahan atau kendala yang dihadapi oleh home imdustry, khususnya dalam segi produk baik secara pengemasan maupun dalam pemasaran. Produk-produk yang kami dampingi selama di PKM ini diantaranya adalah petis khas mandangin, batik tulis, krupuk ikan janggalak dan kripik sukun. Pendampingan yang kami lakukan dalam hal pengemasan (packeging dan labelling), pemasaran (membuat akun di sosial media serta toko online shopee). Metode yang digunakan adalah metode Pengabdian Masyarakat berbasis PAR yaitu pengabdian yang melibatkan semua pihak yang relevan dalam meneliti secara aktif bersama-sama tindakan saat ini yang mereka alami sebagai bermasalah dalam rangka untuk mengubah dan memperbaikinya. Hasil dari kegiatan ini adalah permasalahan yang dihadapi oleh masyarakat pulau mandangin khususnya dalam sektor ekonomi adalah kurang penyadaran dan pelatihan oleh pemerintah setempat mengenai pengemasan dan pemasaran produk unggulan. Apalagi ditahui bahwa desa pulau mandangin akan menjadi desa wisata di tahun ini namun, pemerintah setempat enggan memberikan dampingan khusus atau pelatihan kepada masyarakat tentang pengemasan dan pemasaran produk.
\end{abstract}

Kata Kunci: Pengemasan, Pemasaran dan Produk

\section{PENDAHULUAN}

Didalam kehidupan manusia tidak bisa lepas dengan yang namanya kebutuhan hidup, segala kebutuhan itu tidak lepas dari ekonomi. Melihat kehidupan manusia ekonomi merupakan titik sentral dari kegiatan manusia sehari-hari untuk bertahan hidup. Ekonomi adalah aktivitas manusia yang berhubungan dengan produksi, distribusi, pertukaran, dan konsumsi barang dan jasa. Ekonomi secara umum atau secara khusus adalah aturan rumah tangga atau manajemen rumah tangga. Ekonomi juga dikatakan sebagai ilmu yang menerangkan cara-cara menghasilkan, mengedarkan, membagi serta memakai barang dan jasa dalam masyarakat sehingga kebutuhan materi masyarakat dapat 
terpenuhi sebaik- baiknya. Kegiatan ekonomi dalam masyarakat adalah mengatur urusan harta kekayaan baik yang menyangkut kepemilikan, pengembangan maupun distribusi.

Adapun ekonomi masyarakat adalah sistem ekonomi yang berbasis pada kekuatan ekonomi masyarakat. Dimana ekonomi masyarakat sendiri adalah sebagian kegiatan ekonomi atau usaha yang dilakukan masyarakat kebanyakan dengan cara swadaya mengelola sumber daya ekonomi apa saja yang dapat dibuat usaha, selanjutnya disebut sebagai usaha kecil dan menengah (UKM) terutama meliputi sektor nelayan, kerjainan, makanan dan sebagainya.

Pengemasan merupakan salah satu cara untuk melindungi atua mengawetkan produk pangan. Kemasan adalah datu wadah atau temepat yang digunakan untk mengemas suatu produk yang dilengkapi dengan lebel atau keterangan-keterangan termasuk beberapa manfaat dari isi kemasan. Pengemasan mempunyai peranan dan fungsi yang penting dalam menunjuang distribusi produk terutama yang mudah mengalami kerusakan. Sehingga dapat menambah kualitas produk dan mingkatkan nilai jual abon ikan tongkol, sehingga bisa meningkatkan perekonomian masyarakat.

Menurut Basu Swastha DH, pemasaran adalah sistem keseluruhan dari kegiatan usaha yang ditujukan untuk merencanakan, menentukan harga, mempromosikan dan mendistribusikan barang, jasa, ide kepada pasar sasaran agar dapat mencapai tujuan organisasi, sedangkan menjual adalah ilmu dan seni memengaruhi pribadi yang dilakukan oleh penjual untuk mengajak orang lain agar bersedia membeli barang atau jasa yang ditawarkan. ${ }^{1}$ Didalam kegiatan pemasaran ada strategi pemasaran yang harus dilakukan didalam strategi pemasaran yang harus dilakukan yaitu bauran pemasaran.

Bauran pemasaran merupakan variabel-variabel yang dipakai oleh perusahaan sebagai sarana untuk memenuhi atau melayani kebutuhan dan

\footnotetext{
${ }^{1}$ Danang Sunyoto, Dasar-Dasar Manajemen Pemasaran:Konsep, Strategi, Dan Kasus, (Yogyakarta, CAP, 2013), hal. 18
} 
keinginan konsumen. ${ }^{2}$ Bauran pemasaran terdiri dari empat komponen yeng dikenal dengan 4P yaitu product (produk), price (harga), place (tempat, juga termasuk distribu), dan promotion (promosi). ${ }^{3}$

Pulau Mandangin adalah Desa dan pulau yang berada di kecamatan Sampang, Kabupaten Sampang yang terdiri dari tiga (3) dusun yaitu, dusun Barat, dusun Keramat dan dusun Candin yang merupakan objke PKM, dengan luas pulau 1.650 $\mathrm{km}^{2}$, jumlah penduduknya mencapai 18.000 jiwa. Pulau Mandangin merupakan salah satu tempat wisata di Sampang, dan dapat dijangkau dengan perahu bermotor dari Pelabuhan Tanglok yang terletak dipermukaan kota Sampang. Selain itu, pulau Mandangin dikenal akan keindahan pasir putih, terumbu karang, dan kehidupan masyarakatnya yang mayoritas bermata pencaharian sebagai nelayan.

Di Desa mandangin Dusun Candin (timur) banyak potensi dari sektor perekenomian baik dari segi kerajinan tangan seperti batik tulis dan makanan ringan seperti kripik sukun, krupuk ulin dan petis khas Mandangin. Namun potensi yang ada tidak dikembangkan dengan baik, dari segi pemasaran yang sangat buruk, sehingga penjualan tidak maksimal karena dari produk yang dihasilkan tidak dikembangkan seperti kemasan yang kurang menarik dan masih menggunakan pengemasan seadanya, tidak adanya label membuat daya jual sangat rendah, sehingga banyaknya potensi yang ada tidak maksimal untuk membantu meningkatkan penghasilan masyarakat Dusun Candin.

Masyarakat Desa Pulau Mandangin sangat tergantung pada hasil laut yang mayoritas penduduknya adalah nelayan. Namun yang terjadi di pulau mandangin khususnya Dusun Candin, dari hasil tangkapan ikan yang didapat nelayan tidak dikelola dengan maksimal dan hanya dimasak di dapur sebagai lauk atau dijual dengan harga murah, paling mentok diproduksi menjadi petis. Dari transekt yang

\footnotetext{
2 Basu Swastha Dharmmesta, Manajemen Pemasaran, (Tanggerang Selatan: Universitas Terbuka, 201), hlm. 31

${ }^{3}$ Agus Hermawan, Komonikasi Pemasaran, (jakarta: erlangga, 2012), hal.33.
} 
kami lakukan di minggu pertama, kami dapat menyimpulkan bahwa Dusun Candin memang dusun yang paling tertinggal dari pada Dusun Barat dan Dusun Kramat yang memang sudah banyak ditemukannya potensi yang bisa dibilang bagus.

Selain dari potensi di atas, Dusun Candin sangat berpotensi menjadi tempat wisata, tepatnya dibagian timur yang dikenal dengan nama Candin, memiliki pesona alam yang cukup bagus, akan tetapi mirisnya, banyak sekali penambangan pasir dan sampah yang berserakan sehingga merusak keelokandari Candin tersebut, dan banyak masyarakat mandangin yang tidak mempunyai akta nikah dengan umur pernikahan sekitar 25 tahun, dan banyak pengguna narkoba yang penggunanya didominasi oleh anak muda.

Dalam upaya meningkatkan ekonomi masayarakat yang ada di Desa Pulau Mandangin, maka team PKM melakukan langkah-langkah rencana kegiatan untuk membantu menyelesaikan permasalahan atau kendala yang dihadapi oleh home imdustry, khususnya dalam segi produk baik secara pengemasan maupun dalam pemasaran. Produk-produk yang kami dampingi selama di PKM ini diantaranya adalah petis khas mandangin, batik tulis, krupuk ikan janggalak dan kripik sukun. Pendampingan yang kami lakukan dalam hal pengemasan (packeging dan labelling), pemasaran (membuat akun di sosial media serta toko online shopee).

Setelah memberikan pendampingan selama PKM ini kami bekerjasama dengan BUMDES untuk mengelola dan mengkoordinir semua produk ciri khas mandangin dengan harapan yaitu:

1. Pendampingan kami benar-benar bermanfaat bagi masyarakat pulau mandangin dalam meningkatkan penghasilan tambahan.

2. Pendampingan kami bisa jangka panjang dan berkelanjutan.

3. Produsen bisa kreatif dan mempunyai inovasi baru baik dalam hal pengemasan maupun pembuatan produk.

4. Produk yang kami dampingi bisa bersaing dengan produk lain dengan kualitas yang sama.

5. Produk yang kami dampingi bisa menjadi oleh-oleh ciri khas Mandangin ketika pulau mandangin menjadi pulau pariwisata. 


\section{METODE PENGABDIAN}

Untuk memecahkan masalah yang telah diidentifikasi dan dirumuskan diatas, maka pelaksanaan kegiatan pengabdian ini dilakukan dengan menggunakan metode Pengabdian Masyarakat berbasis PAR yaitu pengabdian yang melibatkan semua pihak yang relevan dalam meneliti secara aktif bersama-sama tindakan saat ini yang mereka alami sebagai bermasalah dalam rangka untuk mengubah dan memperbaikinya. Dalam jenis pengabdian ini adalah suatu proses pencarian pengembangan pengetahuan praktis dalam memahami kondisi sosial, politik, lingkungan,dan juga ekonomi.

Berikut beberapa tujuan dilakukannya pengabdian kepada masyarakat di Dusun Candin Desa Pulau Mandangin Sampang adalah:

1. Untuk membangun kesadaran masyarakat atau memberdayakan masyarakat atas bawah melalui pendidikan kritis, pembelajaran orang dewasa, dialog public, dll

2. Untuk merubah cara pandang tentang penelitian dengan menjadikan penelitian sebuah proses partisipasi

3. Untuk menggeser paradigma masyarakat sebagai objek penelitian

4. Untuk membawa perubahan nilai sosial di masyarakat

\section{HASIL DAN PEMBAHASAN}

\section{A. Perencanaan}

Dari beberapa rencana program yang telah disusun bersama masyarakat ada sekitar 2 program yang menjadi skala perioritas yang akan dilaksanakan. Kedua program tersebut direncanakan bersama warga yang memiliki produk unggulan ciri khas mandangin dan menjadikan program tersebut sebagai suatu solusi dalam meningkatkan penghasilan. Adapun kedua program tersebut adalah pengemasan (packeging dan labelling) dan pemasaran (membuat akun di sosial media serta took-toko online shopee). 
B. Implementasi

1. Pengemasan

kegiatan ini sebenarnya sudah pernah dilakukan oleh pemerintah setempat atau BUMDES namun, kegiatan ini masih belum menyeluruh hanya sebagian saja. Maka dari itu temen-temen PKM berinisiatif untuk mencari produk-produk ungulan ciri khas mandangin diantaranya petis ikan, krupuk ikan jenggelek, kripik sukun dan batik khas mandangin. Dimana, dari produk- produk tersebut masih bersifat sederhana( belum ada label khusus). Berikut proses pengemasan produk.

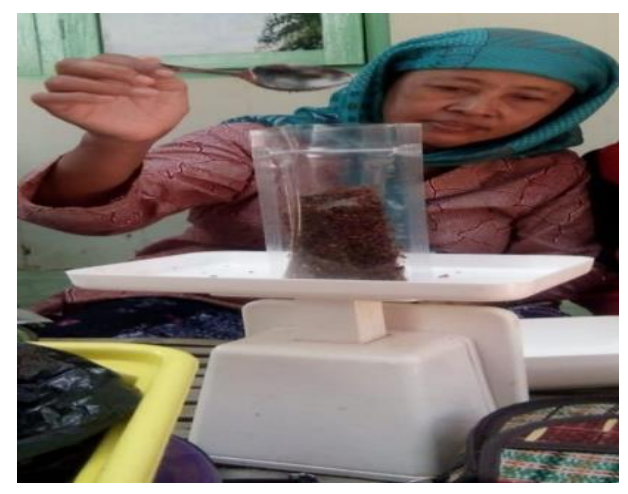

Langkah selanjutnya kami membuatkan sticker (labelling) pada produk unggulan tersebut dan di kasihkan kepada masing produsen. Di sela- sela itu juga kami selalu memberikan dampingan khusus kepada masing- masing produsen agar lebih paham terkait pengemasan (packeging dan labelling). Contoh kemasan produk.

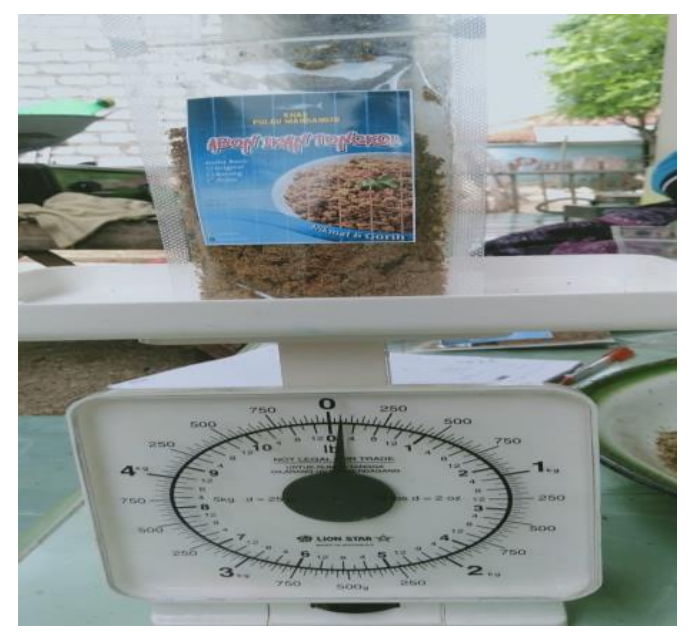




\section{Pemasaran}

Tujuan kegiatan ini adalah membantu meningkatkan penghasilan produsen dalam pemasaran produk-produk unggulan ciri khas mandangn berbasis online. Dimana, kami membuat akun sosial media(facebook) serta toko online(bukalapak). Kegiatan ini juga bekerjasama dengan pemerintah setempat (BUMDES) seperti diketahui dalam pemasaran produk unggulan ini stagnan di pulau mandangin.

C. Evaluasi Dampingan

Pendampingan merupakan upaya terus menerus dan sistematis dalam mendampingi (menfasilitasi) individu, kelompok maupun komunitas dalam mengatasi permasalahan dan menyesuaikan diri dengan kesulitan hidup yang dialami sehingga mereka dapat mengatasi permasalahan tersebut dan mencapai perubahan hidup ke arah yang lebih baik. Terutama pada masyarakat yang memiliki usaha tapi kesulitan dalam hal pengemasan dan pemasaran.

Dari beberapa program yang telah dilaksanakan, temen-temen PKM PAR belum sempat melakukan evaluasi terkait dengan pengemasan dan pemasaran produk-produk unggulan. Hal ini dilatarbelakamgi oleh waktu yang begitu sempit karena durasi waktu yang ditentukan oleh kampus hanya 40 hari itu waktu yang sangat singkat untuk mengevaluasi terkait pekembangan pemasaran produk. Namun, dibalik itu semua kami bekerjasama dengan pemerintah setempat(BUMDES) untuk mengkoordinir serta mengambil alih produk binaan kami dalam jangka panjang.

\section{KESIMPULAN}

Dari semua paparan diatas, bisa disimpulkan bahwa permasalahan yang dihadapi oleh masyarakat pulau mandangin khususnya dalam sektor ekonomi adalah kurang penyadaran dan pelatihan oleh pemerintah setempat mengenai pengemasan dan pemasaran produk unggulan. Apalagi ditahui bahwa desa pulau mandangin akan menjadi desa wisata di tahun ini namun, pemerintah setempat 
enggan memberikan dampingan khusus atau pelatihan kepada masyarakat tentang pengemasan dan pemasaran produk.

Adapun yang sudah kami identifikasi namun belum sempat di evaluasi mengenai peningkatan penghasilan setelah adanya pengemasan dan pemasaran berbasis media online yang rencananya akan diambil alih pemerintah setempat(BUMDES) dalam jangka panjang.

\section{DAFTAR PUSTAKA}

Sunyoto, Danang, Dasar-Dasar Manajemen Pemasaran:Konsep, Strategi, Dan Kasus. Yogyakarta: CAP, 2013.

Dharmmesta, Basu Swastha, Manajemen Pemasaran. Tanggerang Selatan: Universitas Terbuka, 2011.

Hermawan, Agus, Komonikasi Pemasaran. Jakarta: Erlangga, 2012. 